\title{
ON GENERATING CULTURALLY SUSTAINABLE ENTERPRISES AND DEMAND-RESPONSIVE SERVICES IN REMOTE ABORIGINAL SETTINGS: A CASE STUDY FROM NORTH-WEST QUEENSLAND
}

\author{
Paul Memmott
}

School of Architecture and Institute for Social Science Research, University of Queensland, Australia e-mail: p.memmott@uq.edu.au

\begin{abstract}
The catalyst for this paper was the continuation of poor national outcomes in Aboriginal employment and quality of lifestyle, despite 35 years of sustained government service delivery. The persistence of Aboriginal identities and cultures, albeit in transformed states, is a dominant continuity despite the pulses and shifts of policies. Nevertheless, debate has recently embraced whether Aboriginal people can participate in the market economy and yet still retain traditional culture (Sarra 2009), and whether retention of traditional culture has contributed inadvertently to community dysfunction (Altman 2009; Sutton 2009). The paper explores a case study of remote Aboriginal cultural and socioeconomic empowerment situated within the fields of both mainstream economy and service delivery in the Myuma Group. From the research, there is a range of significant good-practice strategies and methods underpinning Myuma's success. In historical order, the first was the use of a native title claim from which to obtain an initial set of economic assets (infra structure, contracts). A second strategy was an inclusive (rather than exclusive) approach to spreading the enterprise benefits created by a small Indjilandji extended family group to a regional bloc of multiple language groups and to other beneficiaries in the wider community. This enabled the Myuma Group to project itself as a benefactor for the regional Aboriginal population (not simply as a nepotistic family-based firm) an image that was essential to attract strong government support and local and regional legitimacy.
\end{abstract}

Keywords: Aborigin, demand-responsive service, sustainable enterprise

\begin{abstract}
ABSTRAK
Hal yang mendasari artikel ini adalah berlanjutnya dampak kemiskinan nasional pada pekerja Aborigin dan kualitas gaya hidup, walaupun 35 tahun ditopang layanan pemerintah. Kuatnya identitas dan budaya Aborigin, walaupun dalam keadaan
\end{abstract}


transformasi, terus berlanjut dominan walaupun terjadi perubahan dalam kebijakan politik. Meskipun demikian, perdebatan yang baru saja terjadi mengenai apakah orang Aborigin bisa berpartisipasi dalam pasar ekonomi padahal masih bertahan dalam budaya tradisional (Sarra, 2009) dan apakah bertahannya budaya tradisional secara tidak sengaja memberikan kontribusi terhadap tidak berfungsinya komunitas (Altman, 2009; Sutton, 2009). Penelitian ini mengeksplorasi sebuah studi kasus pada budaya Aborigin yang terpencil dan penguatan di bidang sosial-ekonomi yang terjadi di daerah studi dalam pola pikir ekonomi dan servis pelayanan pada kelompok Myuma. Dari penelitian, terdapat rentang strategi pelaksanaan yang bagus dan metode yang mendasari kesuksesan Myuma. Dari sisi sejarah, hal pertama adalah penggunaan judul klaim asli untuk mendapatkan aset ekonomi (infrastruktur, kontrak). Strategi kedua adalah pendekatan inklusif (daripada eksklusif) untuk menyebarkan keuntungan bisnis yang diciptakan oleh indji-landi, sebuah perluasan grup keluarga pada blok kawasan multi bahasa dan kepada komunitas benefisiari lainnya. Hal ini memungkinkan kelompok Myuma untuk memproyeksikan diri mereka sebagai sukarelawan dari populasi Aborigin di kawasan (tidak semudah sistem nepotisme pada perusahaan). Sebuah gambaran yang penting untuk menarik dukungan kuat pemerintah dan legitimasi lokal dan kawasan.

Kata kunci: Aborigin, permintaan-pelayanan yang responsive, bisnis berkelanjutan

\section{INTRODUCTION}

For those many Aboriginal groups who do not wish to leave their traditional homelands and communities, one consistent challenge for their leaders and trusted advisors is to generate remote Aboriginal economies that are embraced by Aboriginal people. A second challenge is to ground these economies in Aboriginal culture and social capital, so as to assist in the veracity and persistence of the latter; and third, to seek a 'fit' between financially viable enterprise and voluntary economic behaviour in the local market conditions such that people are motivated to participate in such economies. In this chapter, I contend that such motivation can come from the fulfilment of demand-responsive service provision in remote communities, and that achieving such a symbiotic service delivery in remote communities that are marginal to mainstream economic markets is necessary to ensure viable health, quality of lifestyle, social cohesion and wellbeing. Service delivery encompasses the provision of such things as food, cars, music, religion, governance, housing, water, health treatment, recreational infrastructure and many other tangible and intangible commodities. Service delivery needs to be designed and cross-linked to satisfy both perceived needs and consumption styles or choices. In itself, consumption also needs to be considered and analysed as a form of self-definition and of cultural identification and process.

In this paper, I explore a case study of remote Aboriginal cultural and socioeconomic empowerment situated within the fields of both mainstream economy and service delivery. The Myuma Group is comprised of three interlinked Aboriginal corporations centred on the upper Georgina River in far western Queensland, which 
were established by the local traditional owners, the Indjalandji-Dhidhanu people. The Myuma Group first established a principal work camp on the outskirts of Camooweal (a township near the Queensland Northern Territory border), then a second work camp at a remote limestone quarry, and an office in Mount Isa (Figure 1). From these three bases, they administer a combination of enterprises, training, service delivery and cultural heritage activities.

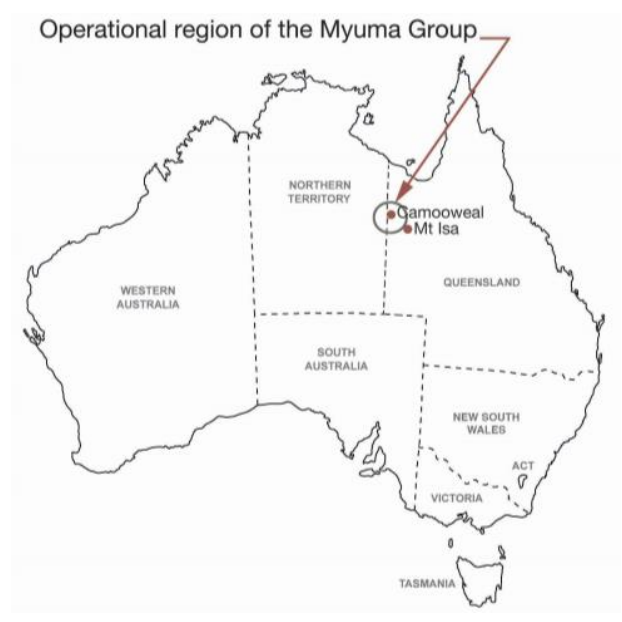

Figure 1. Operational Location of the Myuma Group

\section{THEORY / RESEARCH METHODS}

\section{The Georgina River Frontier History}

In the mid-nineteenth century, the Indjalandji-Dhidhanu people occupied the upper Georgina Basin and surrounding Barkly Tableland in far north-west Queensland. A young Dhidhanu man named Idaya, a forebear of the contemporary group, was alive at this time. The first impacts of colonisation were in December 1861, when the explorer William Landsborough encountered and renamed three sacred Indjalandji waterholes on the Georgina River as Lakes Mary, Francis and Canellan. His favourable report on the surrounding grasslands triggered several waves of pastoral occupation by colonists during 1864-84. The township of Camooweal was established beside Lake Francis in 1884 and was to flourish as a border customs post, a pastoral industry service town and a droving stop for the 'cattle barons' bringing cattle from the Barkly Tableland and the Kimberley to the eastern coastal markets.

Decimation of the Aboriginal groups of the Georgina occurred in parallel during the late nineteenth century and was largely attributable to frontier violence, as well as multiple infectious and contagious diseases. Only a few IndjalandjiDhidhanu families survived, together with remnants of the neighbouring Kalkadungu, Bularnu and Waluwarra tribal groups, providing cheap labour for the pastoral industry. Partly in response to the widespread demographic collapse, the Queensland 
Government introduced the Aboriginals Protection and Restriction of the Sale of Opium Act 1897, which regulated, but also forced, Aboriginal people to labour in the pastoral industry (arguably an economic mode of internal colonialism; see White 2011). Uncooperative workers were sent to institutionalised penal settlements in the east of the State such as Cherbourg, Woorabinda and Palm Island.

The descendants of Idaya lived in the pastoral camps and town camps as they worked under 'the Act' and intermarried with spouses from these other tribal groups. The contemporary elder of the Myuma Group, Ruby Saltmere, was born in 1933 at a traditional birthing camp. Ruby's uncle Dijeru Jack (the grandson of Idaya) performed rainmaking rituals to green the country at the request of the local pastoralists, and maintained the group's link to the rainmaking site of Dugalunji. A sense of a Georgina River Aboriginal culture and community survived. Ruby Saltmere sums this up by saying 'as for the country part of it, well, we know the country because we been here all our life and worked on it'.

\section{Levering up Myuma from Native Title}

In 1998, the descendants of Idaya submitted a native title application under the Native Title Act 1993 (Cwlth) over a part of the Georgina River around Camooweal including Lakes Francis and Canellan. In 1999 the development progress of a proposed new Georgina River bridge by the Queensland Main Roads Department was stymied by two competing native title claims, but an independent review of the historical and contemporary ethnographic evidence indicated that the Indjalandji claimants were the appropriate traditional owners for the bridge site (Memmott and Stacy 1999), which allowed them to commence negotiation with Main Roads over progressing the bridge. A second issue was a strong objection by the elder Ruby Saltmere to sinking deep pier footings for the bridge within the riverbed, as she believed this would harm the Rainbow Serpent's back that had metamorphosed into the bedrock of the river (and which would unleash an environmental catastrophe). Main Roads engineers designed a system of pad footings such that the piers could sit on top of the river bedrock without penetrating it. A third issue was the implementation of additional environmental management principles required by the Indja-landji claimants to protect cultural heritage sites and other natural features (Archaeo and Dugalunji 2002).

The construction of the bridge was then able to proceed. The Indjalandji, using their native title claimant status, managed to negotiate outcomes and benefits from Queensland Main Roads, including employment and training for themselves and Aboriginal members of the wider community. In addition, a construction camp (the 'Dugalunji Camp') was established in 2001 by Main Roads within the Camooweal Town Common for use by the group. It was agreed that after the completion of the bridge, the site of the construction camp would be left in the hands of the Indjalandji group, to assist the groups to participate in the subsequent highway upgrades. The bridge was officially named Ilaga Thuwani, meaning 'The Camping Ground of the Rainbow Serpent'. The Queensland Government viewed the bridge project as a successful partnership (DATSIP 2005:24). 


\section{Profile of The Myuma Group}

By 2002, the Indjalandji-Dhidhanu Group of Traditional Owners at Camooweal established the Myuma Group of corporations to further the wellbeing, cultural maintenance and quality of lifestyle of their people as well as the Aboriginal people of their region. The Myuma Group came to consist of three corporate entities, each with a different function: Myuma Proprietary Limited, Dugalunji Aboriginal Corporation and Rainbow Gateway Limited (Table 1). The group's leader, Colin Saltmere, progressed from being a pastoral 'ringer' to the Managing Director of Myuma.

Myuma Proprietary Limited is a non-profit proprietary company, incorporated for the purposes of managing the business arm of the group's activities. Its constitutional objectives are to promote and benefit the welfare of the Aboriginal communities of the upper Georgina River region, but in recent years it has expanded geo-graphically to assist people throughout the greater part of north-east Australia. Myuma Proprietary Limited runs an enterprise operation (including labour and plant hire) and also employs and delivers accredited training programs to local Aboriginal people in civil and mining construction and related support services (horticulture, hospitality and catering). At the time of writing, the number of workers employed by Myuma ranged between 40 and 80, 90 per cent of whom were Aboriginal. Myuma purposefully engaged people from their neighbouring traditional owner Aboriginal groups as employees and trainees in all projects (Figure 2).

The Dugalunji Aboriginal Corporation is a not-for-profit organisation whose core business is management of the group's native title and cultural heritage interests. This includes land and riverine management activities, and the provision and management of cultural heritage services to clients. Myuma Proprietary Limited assists Dugalunji to deliver employment/training outcomes to local Aboriginal people in cultural heritage practices. Rainbow Gateway Limited acts as a tax-deductible charity that receives and distributes any net incomes from Myuma Proprietary Limited and Dugalunji Aboriginal Corporation for use in addressing the charitable goals of the Indjalandji-Dhidhanu.

Table 1. The Three Corporate Vehicles of the Myuma Group and their Respective Spheres of Operation

\begin{tabular}{ll}
\hline Corporate vehicle & Sphere of operation \\
\hline Myuma Pty Ltd & Economic enterprises, training \\
$\begin{array}{l}\text { Dugalunji Aboriginal } \\
\text { Corporation }\end{array}$ & $\begin{array}{l}\text { Cultural heritage, native title, land and riverine } \\
\text { management }\end{array}$ \\
Rainbow Gateway Ltd & Social, welfare and charitable projects \\
\hline
\end{tabular}




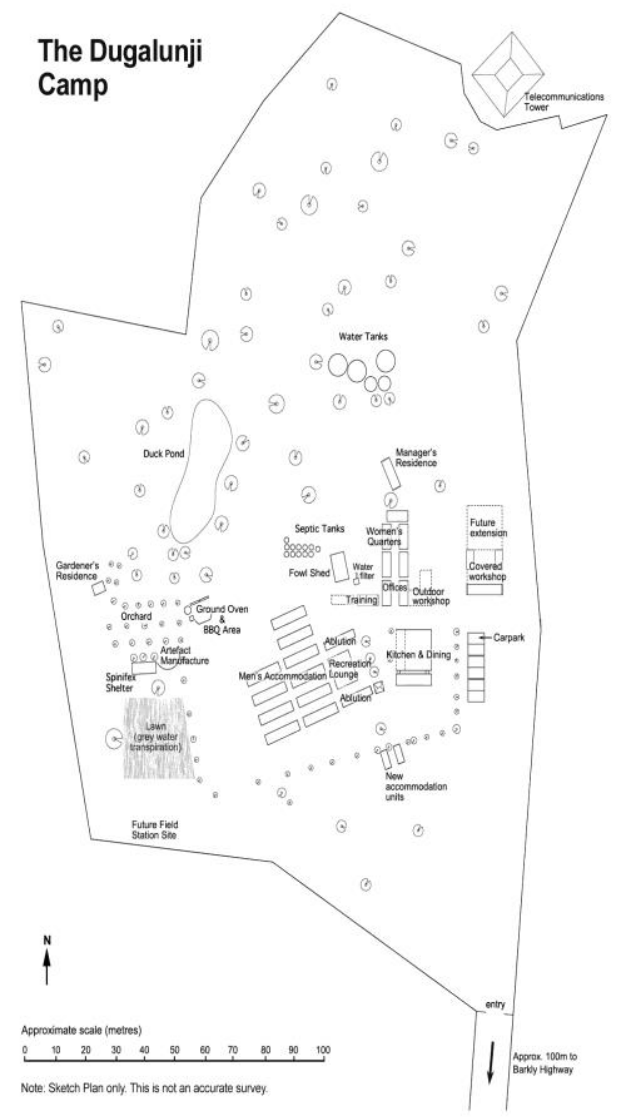

Figure 2. Plan of Myuma Camp in 2006

\section{RESULTS AND DISCUSSION}

\section{Training Delivery by The Myuma Group and Partners}

From its early stages, Myuma's leaders recognised that ample employment opportunities for Aboriginal trainees existed within Myuma's own operations as well as within the many civil construction and mining companies operating in the region. The Myuma Group forged close working relationships with key industry stakeholders, including regional job network agencies and Community Development Employment Projects (CDEP) organisations, Australian Government agencies, State Government agencies, registered training organisations that were Australian Quality Framework (AQF) compliant and peak industry groups. From this network, a consultative committee was formed to develop a training management model that emphasised a set of key learnings. First, the committee had to be proactive in scoping forth coming onsite training opportunities and associated project proponents who would be willing to engage in an Aboriginal training program. Second was the need for the committee to take a collective approach to identifying and pooling 
available government resources for the respective costs incurred by trainees, training organisations and onsite employers. Third was the need for early engagement between the training agency and the identified project proponent and their project contractor on the issues of design, delivery and integration of training into the contract work onsite. A final learning was the importance of identifying the particular needs of trainees between exiting their training program and entering their available employment option; in some cases, this involves the provision of further short, specialised training packages.

During 2006, the Myuma Group and its partners designed and trialled a pre vocational, accredited, individualised training program that delivered competencies specifically chosen to equip Aboriginal participants for preidentified, full-time, entry-level industry positions. During 2007-08 the demographic profile of trainees broadened to take in both remote and urban communities throughout the Gulf of Carpentaria, Cape York, north Queensland and the far east of the Northern Territory. This broadened set of community sources facilitated a more careful selection process, maximising opportunities for those with high motivation and unfulfilled capacity, including from remote communities characterised as having dysfunctional traits. The geographic diversity ensured a stimulating multicultural interactive experience between trainees from diverse and different Aboriginal cultures. Some of them (for example, the Wik from Aurukun) were steeped in aspects of Aboriginal law, whilst other, urban trainees had largely missed out. At the end of 2009, informal agreements were in place with a number of Aboriginal community councils or non-governmental organisations (NGOs) from whom to regularly recruit trainees, including at Aurukun, Yarrabah, Palm Island, Mossman and Innisfail.

Participants were largely Aboriginal school-leavers or persons who were either long-term unemployed or at risk of long-term unemployment. Each training intake was largely made up of 30 young adults in the eighteen to twenty-six-year age range and with a mixture of men to women in the ratio of about five to one. Participants were usually recruited in groups of three, four or five from each targeted community such that upon arrival there were some familiar faces with whom one could interact. The social relatedness grew as individuals found themselves in different work teams and activity groups.

The pre-vocational training curriculum involves three accredited streams: 1) civil construction, 2) mining, and 3) life skills. The program aims to foster an emergence of diverse Aboriginal identities within the trainee group based on Aboriginal values, to strengthen individual confidence, to express their particular identity and to be able to contrast their identity with those of others. Aboriginal cultural identity and religion workshops have enhanced Aboriginal values of relatedness to others as well as to country and sacred sites, whilst family violence workshops have addressed issues of having one's employment undermined by home family problems. All of these components aimed to provide a strong foundation for young Aboriginal adults in the workplace embracing physical, psychological and skills performance. On-the-job practical experience also occurred during the training through a series of short work-team placements. The trainees have assisted Myuma in the delivery of existing contracts and works, including the execution of a range of well-supported public infrastructure projects chosen to yield long-term benefits to 
the residents of the Camooweal region and the travelling public, of which the trainees were able to feel justly proud in terms of their role in improving community services.

The mode of running the Dugalunji Camp was a critical factor underlying the success of the training program. The Myuma Managing Director, Colin Saltmere, operated the camp like a boarding school for young Aboriginal adults, providing a set of life skills and industrial discipline for the trainees. Problems certainly have arisen, given that the trainee intake has often included individuals with substance abuse addiction, insecurity about their Aboriginality, and immaturity about adulthood, and who have sometimes engaged in violent behaviour and in living outside of the Australian law in various ways. Nevertheless, the Myuma training course has maintained a high retention of trainees during the course and a high rate of graduation (86 per cent). Of the 105 trainees who graduated during 2007-09, some 69 (66 per cent) obtained employment upon graduation; about one-third then remained in continuous employment for at least six months (Memmott 2010: Table 2).

\section{Services to Aboriginal Workers and Trainees}

Myuma Proprietary Limited provides a range of key services and facilities to its Aboriginal workers and trainees in response to their expressed needs. Many of these services and facilities have been built up with the economic gains from Myuma's enterprise work. The Dugalunji camp environment is a substance-free Aboriginal living area with nutritious meals and some recreation facilities for example, a sports field, pool table, television lounge and small gymnasium. Myuma provides a private room for each of its employees and trainees, which for a good number of them is the first fully private space they have ever occupied and personalised. At the Dugalunji Camp, Aboriginal leaders have chosen when to facilitate or broker particular forms of service delivery. This form of participation and engagement is viewed as being essential to obtain sustainable outputs from service delivery.

Myuma staff act as informal social workers, counsellors or 'errand runners' to maintain harmony and wellbeing in the Dugalunji Camp. Above all, the Dugalunji Camp provides workers and trainees with a calm residential setting, relatively free of problems or chaos, where people can feel at home in the world for a while, and where relatedness enfolds for many with their fellows in the camp (after AustinBroos 2009). Camp harmony results from intra-group harmony, which in turn results from the requirement of a strong personal moral code conveyed through the camp rules and the authoritative guidance of Colin Saltmere as camp boss. The Myuma pre-vocational program has encouraged the development of a career narrative and a purpose in life. It has opened a window to alternative lifeways and career pathways that might not have been apparent or available in the home communities of the trainees.

\section{Recognition of Myuma's Good Practice in Service Delivery}

A range of indicators readily identifies Myuma's good practice as a service provider, specifically private-sector contracts for the supply of pre-vocational trainees to 
continue, including the production of a marketing video by the Queensland Department of Transport and Main Roads highlighting the good practice achieved in Myuma, for use in promoting reconciliation and upskilling via partnerships between Aboriginal communities and the Government. Colin Saltmere speaks on the film about 'building people', emphasising the holistic development of the individual, in addition to the other achievements of workplace alliances and skills development (DTMR 2009). Yet further indices of Myuma's good practice are: consistent and stable annual growth reflected in Myuma's annual gross turnovers; the winning of a host of State and national industry awards for training, reconciliation and cultural heritage achievement; and a Commonwealth infrastructure grant of $\$ 3.8$ million awarded to Myuma for the upgrading of its training facilities (Memmott 2010).

\section{Myuma as a Complex Aboriginal Adaptive System within the Market}

In contrast with directed consumption in many arid-zone communities whereby services are delivered unidirectionally downwards by government sponsored agencies, the author's research aim was concerned with how demand-driven service delivery could be attained by Aboriginal communities, such that a more bidirectional and lateral (or transactional) relationship could be achieved between consumer communities and service providers, resulting in a better response of service supply to demand (or a demand-driven service delivery).

Due to its distinctive economic history, Myuma has become positioned in the market with complex supply and demand functions (or multiple diversified market inter-facing). In the 2004-05 financial year, the Myuma Group contributed a total of $\$ 3.6$ million to the local economy through its payment of wages for employment and training of local labour and the purchase of local services, supplies and products. In the four subsequent financial years (to the end of June 2009), the contributions to the local economy did not fall below this amount and ranged upwards to $\$ 6.1$ million (Table 2).

Table 2. Myuma's Contribution to its Regional Economy, 2004-09

\begin{tabular}{ll}
\hline Financial year & $\begin{array}{l}\text { Contribution to local } \\
\text { economy }\end{array}$ \\
\hline $2004-05$ & \$3.6 million \\
$2005-06$ & $\$ 4.2$ million \\
$2006-07$ & $\$ 6.1$ million \\
$2007-08$ & \$3.6 million \\
$2008-09$ & \$4.2 million \\
Total (five years) & \$21.7 million
\end{tabular}

The total contribution over five financial years has been almost $\$ 21.7$ million an average of \$4.34 million. These contributions have come via Myuma's enterprise and training contracts. Part of this monetary contribution (including charitable community-based services) goes into the township of Camooweal, assisting to 
reawaken its gentrified economy (decline occurred when its pastoral function was superseded by mechanised stock transport and mustering technology).

The reader is thus asked to consider a market participation model in which there are complex demand and supply chains and networks (read in conjunction with Figure 3). Suppose I am to supply a service, $X$, in the market: in order to do this, I have to demand Y goods and Z services. The entities that supply $\mathrm{Y}$ and Z, however, also want my supply of $X$, or alternatively want me to maintain the supply of $X$, which stimulates the trade of their goods and services in other parts of the market. Thus, demand is partly driven by the capacity to supply (not just to consume), as well as by the reciprocal appreciation of the mutual demands and needs for one another's services. Accountability becomes more lateralised with marketplace performance, with many players in the economic chain interdependent upon one another, as opposed to vertical accountability in a top-down service to bottom-up demand context typical of many remote Aboriginal communities. In the theoretical literature on human consumption, this more complex set of market relationships is termed 'productive consumption'. The 'act of production is therefore in all its moments also an act of consumption. Production as directly identical with consumption, and consumption as directly coincident with production' (Marx 2001:32).

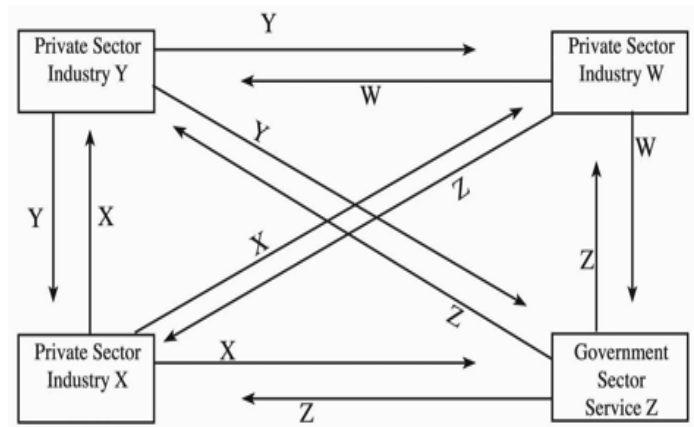

Figure 3. The Market Participation Model: Complex Demand and Supply Chains and Networks

A key challenge for Aboriginal groups is how to 'lever' themselves out of welfare dependency and to insert themselves into the market without substantial 'start-up' resources. The Myuma Group provides a case study of how to achieve this status. This positioning of Myuma in a complex network or field of supply and demand can be termed a 'transactional model of supply and demand'. In adjusting 'the playing field' of service delivery to be 'level' with a degree of demand-driven consumer choice, there was a need for Myuma to earn some power within market relationships and transactions, and for Myuma to take some control over information (informed consumerism) and decision-making capacity based on that information, thereby facilitating active engagement and negotiation on the terms of its Aboriginal consumers (trainees and workers).

A further critical method employed by Myuma to achieve this position is the design of the Dugalunji Camp as an 'Aboriginal service setting', in contrast with a 
government service setting or a commercial service setting. An Aboriginal service setting can be defined as one that is largely controlled by Aboriginal people and is designed to be comfortable for Aboriginal consumers (Figure 4). There is a sense of identity with and even ownership of such a setting by Aboriginal people when the service is being delivered in an effective way.

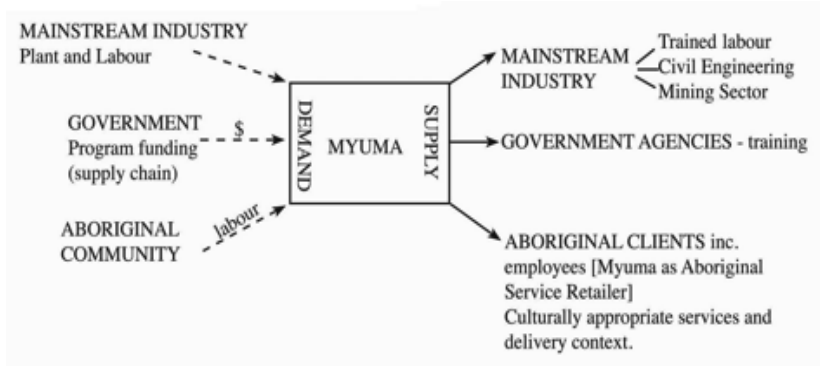

Figure 4. Myuma as the Complex Indigenous Adaptive System

A key role of the Aboriginal service setting is to 'level the playing field', so to speak, and alter the imbalance of power that has often characterised many transactions with Aboriginal people in government and commercial delivery settings, whereby delivery is one way with either no opportunity for Aboriginal negotiation as a consumer or the prospect of such negotiation being intimidated by discriminatory practices. Although I have here employed the term 'Aboriginal service setting' to describe the Dugalunji Camp, it is more accurately an inter-cultural setting with a dominance of Aboriginal behavioural patterns and with ultimate Aboriginal control and management.

\section{Critical Human Resources within the Myuma Group}

Any profiling of Myuma and its achievements would be incomplete without some discussion of the role and calibre of the human resources that drive Myuma both from within and from outside its corporate framework. Foundational support is provided within the directorships of the Myuma Group by the Indjilandji-Dhidhanu group, and although some families are more active than others in the day-to-day company affairs and particular projects, they consistently gather for board meetings to make critical decisions. These decisions are not just restricted to new contract engagements or what to do with profits, but also encompass the wider concerns of the group, such as maintaining Indjalandji Aboriginal law and custom and matters of local Aboriginal community politics and social development. In this regard, Ruby Saltmere has played a dominant role as the group's elder and keeper of extensive cultural knowledge. Nevertheless, the day-to-day roles of being the 'focal driver' for Myuma and the lead negotiator with other communities, governments and industry are clearly taken by her son, Colin Saltmere, as Managing Director, albeit assisted by his senior staff. Myuma's success is not just attributable to strong leadership, but also to a solid foundation of corporate teamwork, involving both staff and traditional 
owner directors, as well as the supportive network of outside advisors and advocates for the Myuma Group, who come from diverse trades, professions and life paths.

\section{The Relationship between Myuma's Activities and Aboriginal Law}

The Myuma Group's practice is based on a strong commitment to Aboriginal law and culture. This is in defiance of the late Professor W. E. H. Stanner who asserted that the Dreaming and the market were incompatible: 'Ours is a market-civilisation, theirs not. Indeed, there is a sense in which The Dreaming and The Market are mutually exclusive' (Stanner 1979:58). Despite Stanner's views, the strong commitment to law and culture continues to permeate through the Dugalunji Camp on a daily basis via a number of mechanisms and behaviours that include: 1) the visitation and residence of regional elders at the Dugalunji Camp who engage in a variety of customary activities including hunting; 2) the regular contracting of cultural heritage services to industry by Dugalunji; 3) the running of cultural induc-tion programs for regional industry workers; 4) the workshops on cultural identity strengthening for pre-vocational trainees from throughout north-east Australian cultural groups (numerous tribal identities); 5) the involvement of the Indjalandji in regional Aboriginal ceremonies; and 6) an ongoing program of Indjalandji sacred site recording in the region. The provision of cultural services to industry is one component of Myuma's hybrid economy along with road maintenance, fencing, land management and training contracts.

The Indjalandji elders' and leaders' respect of Aboriginal law and sacred sites gradually pervades into the awareness of staff, trainers and visitors. They become aware that they are in a cultural landscape of ancestrally created places and histories. There is thus a unique symbiotic relationship between the practice of Aboriginal law and the practice of commerce in the Dugalunji Camp whereby the two are mutually supportive of one another, generating a strong Aboriginality in the way that day-today 'business' is run by Myuma. This is directly projected on to the trainees who gain increased confidence in their own cultural identities and return to their home communities with a strengthened sense of their Aboriginality.

\section{CONCLUSIONS}

There is a range of significant good-practice strategies and methods underpinning Myuma's success. In historical order, the first was the use of a native title claim from which to obtain an initial set of economic assets (infrastructure, contracts). A second strategy was an inclusive (rather than exclusive) approach to spreading the enterprise benefits created by a small Indjilandji extended family group to a regional bloc of multiple language groups and to other beneficiaries in the wider community. This enabled the Myuma Group to project itself as a benefactor for the regional Aboriginal population (not simply as a nepotistic family-based firm) an image that was essential to attract strong government support and local and regional legitimacy.

Acting as an Aboriginal host organisation, Myuma has accomplished a viable integration of economic enterprise activity and service provision, involving the 
following processes: 1) attracting a large-scale contract with government or private enterprise that can be fulfilled with largely Aboriginal labour; 2) hosting the Aboriginal labour onsite with accommodation, meals and a social and service environment that is culturally appropriate, so that the employees feel comfortable; 3 ) providing accessible training courses to the labour pool relevant to the work experience, so there is added value for the employees and so that the labour force acquires ongoing, diverse skill sets; and 4) attracting more enterprise and training contracts to achieve a stable continuity of employment, training and hence accompanying ongoing service provision. This has resulted in Myuma becoming part of the local and regional economic market, which partly explains its capacity to secure selected and culturally modified demand service needs from the government and business sectors. Further critical factors underlie the Myuma success story. First is Colin Saltmere's leadership skill in being able to not only successfully influence and negotiate in the mainstream government and business world, but also simultaneously earn the respect of Aboriginal people by being a customary law authority and leader in the Barkly region. Second, Myuma has gained a reputation for professional levels of performance, generating widespread respect from both industry and government. Third is the pre-vocational training in an Aboriginal-run and controlled work camp, which doubles as an Aboriginal service setting, and in which most cross-cultural blockages and intimidations experienced by trainees can be worked through with a trusting training team. This results in 'closing the gap': 'not just job readiness, but having jobs ready' for the Aboriginal trainees again, a function of Myuma's good standing in the economic market (Memmott 2010).

The value of the Myuma case study has thus been to profile an Aboriginal group which has been capturing both lateral (industry) and vertical (government) resource flows within its unique structure and integrating those resources to control service delivery in certain ways at the local level for the good of a regional Aboriginal collective. Such case studies are important in understanding techniques for creating a relatively stable socioeconomic position of both enterprise and service delivery under local political control, which is in turn partially insulated against any possible future fluctuations of either government or private resourcing.

In summary, it can be said that the Myuma experiment denies socioeconomic disadvantage as being an Aboriginal destiny. Myuma aims to lift young Aboriginal adults out of such disadvantage and 'provide for them, a prospect that they would otherwise not have, that their parents never had' (Pearson 2009). Through the device of the Aboriginal service setting, Myuma is able to provide its trainees and workers with a sense of 'at-homeness', of residential harmony and social relatedness of order and security experiences that are often in contrast in particular ways with their home community life. Myuma, in light of the evidence at hand, is a nationally significant example of Indigenous people overcoming 'extraordinary hurdles to foster emergent social norms and new institutions' (Altman 2009) based on a culturally accommodating hybrid economy, a dialectic resolution that surmounts opposition between cultural idealism and economic pragmatism, overcomes mainstream left-wing and right-wing political myopias, and lands somewhere in 'the radical centre' to follow Pearson's recent prescribed position (Pearson 2009:248; Sutton 2009). 


\section{REFERENCES}

Altman, J. (2009), What liberal consensus, Book review of Sutton's The Politics of Suffering, New Matilda, <http://newmatilda.com/2009/07/16/ what-liberal-consensus>, (Accessed on 16 July 2009).

Archaeo and Dugalunji (2002), Cultural Heritage Excavation and Collection: Georgina River Bridge Cultural Heritage Project, Camooweal, northwest Queensland, Report to Department of Main Roads, EPA Permit N14/EIS/2000, October 2000 - December 2002.

Austin-Broos, D. (2009), Workfare, welfare and the hybrid economy: the Western Arrernte in Central Australia. Paper delivered at the Indigenous Participation in Australian Economies Conference, National Museum of Australia, Canberra, 10 November 2008.

Barker, R. (1968), Ecological Psychology. Stanford University Press, California.

Barker, R. and Wright, H. (1955), Midwest and its Children. The psychological ecology of an American town. New York: Row, Peterson \& Company.

Department of Aboriginal and Torres Strait Islander Policy (2005), Partnerships Queensland: Future directions framework for Aboriginal and Torres Strait Islander policy in Queensland 2005-10. Brisbane: Government Printer.

Department of Transport and Main Roads (2009), Building Indigenous Capability A remote employment and training partnership that works. (Film.) Brisbane, Queensland Department of Transport and Main Roads.

Marx, K. (2001), Introduction. In D. Miller (ed.), Consumption: Critical concepts in the social sciences, pp. 32-6. London: Routledge.

Memmott, P. (2010), Demand Responsive Services and Culturally Sustainable Enterprise in Remote Aboriginal Settings: A case study of the Myuma Group. Alice Springs, NT: Desert Knowledge Cooperative Research Centre.

Memmott, P. and Stacy, R. (1999), Independent Anthropological Study on the Proposed Georgina River Bridge Site Camooweal, Qld. Job No. 10/15C/2, Prepared for Main Roads, Queensland. St Lucia, Qld: Paul Memmott and Associates.

Moran, M. (2006), Practising self-determination: participation in planning and local governance in discrete Indigenous settlements, $\mathrm{PhD}$ thesis, School of Geogra-phy, Planning and Architecture, University of Queensland, Brisbane.

Paul Memmott and Associates (2007), The Myuma Group, Georgina River Basin Aboriginal enterprise, training and cultural heritage. Mount Isa, Qld: Myuma Proprietary Limited.

Pearson, N. (2009), Up from the Mission: Selected writings. Melbourne: Black Inc.

Stanner, W. E. H. (1979), Continuity and change among the Aborigines. In W. E. H. Stanner (ed.), White Man Got No Dreaming: Essays 1938-1973, pp. 41-66. Canberra: Australian National University Press.

Sutton, P. (2009), Here I stand: Noel Pearson's Up from the Mission, Book re-view, The Monthly (46) (June).

White, J. (2011), Histories of Indigenous-settler relations: reflections on internal colonialism and the hybrid economy. Australian Indigenous Studies (1): 81-96. 